\title{
Nutrient utilisation and particulate organic matter changes during summer in the upper mixed layer (Ross Sea, Antarctica)
}

\author{
G. CATALANO, ${ }^{*}$ P. POVERO $\dagger$ M. FABIANO $\ddagger$ F. BENEDETTI $\S$ and \\ A. GOFFART
}

(Received 26 November 1995; accepted 4 June 1996)

\begin{abstract}
The relationships among vertical stability, estimated nutrient utilisation and particulate organic matter in the Ross Sea are analysed from data collected during two cruises in the summers of 1987-88 and 1989-90. In the upper mixed layer (UML), identified through the vertical stability $E(Z(\mathrm{UML}))$, nutrient consumption is calculated as the difference between the "diluted" nutrient value and the mean calculated from the integrated value in the UML. The nutrient utilisation ratio and $E(Z(U M L))$ are linearly related for $E(Z(U M L)) \leq 25$, whereas for values $>25$, the distribution pattern is more scattered and independent of $E(Z(\mathrm{UML}))$. For $E(Z(\mathrm{UML})) \geq 25$, utilisation values were $\geq 4,0.4$ and $10 \mathrm{mmol} \mathrm{m}^{-3}$ for nitrate, phosphate and silicate, respectively. Significant relationships between nutrient depletion and both particulate organic carbon (POC) and particulate protein/particulate carbohydrate ratios (PPRT/PCHO) are found. The analysis of particulate matter distribution vs nutrient utilisation shows that the stations could be divided into two groups having different characteristics. The first group includes coastal stations, where high nutrient utilisation, POC and PPRT/PCHO are typical of areas with high production. In the second group (pelagic stations), nutrient utilisation, POC and PPRT/PCHO are lower. The vertical stability can be used to discriminate among the factors that influence primary production. (C) 1997 Elsevier Science Ltd. All rights reserved
\end{abstract}

\section{INTRODUCTION}

Sea-ice is recognised as a key habitat for polar marine biota both as a substrate for living organisms (sea-ice communities) and as a factor affecting population dynamics. With the annual advance and recession cycles, sea-ice zones strongly influence production in the euphotic layer, which alternates between periods of enhanced growth and comparatively reduced production. Sea-ice melting at the edge of the pack creates a favourable situation for intense phytoplankton blooms and the onset of blooms can be ascribed to the stable environment created by the flux of less dense meltwater and to the "inoculum" effect of epontic algae for primary producers (Smith and Nelson, 1985).

It is also recognised that, after a phase in which production is very high, the phytoplankton growth decreases, although the full productive potential of the Antarctic seas is not fully exploited. The limits on phytoplankton growth and accumulation, although actively investigated for many years, are still controversial. The most likely causes for the

\footnotetext{
* CNR, Istituto Talassografico, Trieste, Italy.

† Istituto di Scienze Ambientali Marine, Università di Genova, Genova, Italy.

† Cattedra di Ecologia, Università di Ancona, Ancona, Italy.

§ Dipartimento di Scienze Chimiche, Università di Trieste, Trieste, Italy.

Institut de Physique, Universitè de Liege, Liege, Belgium.
} 
lack of complete nutrient removal are light limitation, nutrient depletion, micronutrient availability, grazing pressure and, finally, vertical stability of the water column (Niebauer and Alexander, 1985; Smetacek, 1985; Smith and Nelson, 1985; Nelson et al., 1989; Nelson and Treguer, 1992).

The waters surrounding Antarctica are now considered not as a single functional unit but rather as a mosaic of subsystems (Treguer and Jacques, 1992) in which each factor, either supporting or limiting phytoplankton productivity, can act either independently or in conjunction with others. Therefore the choice of the geographical area to be investigated can imply a type of functional subsystem and set a "bias" on the study of the likely mechanisms controlling productivity.

The Ross Sea area, where most of the work during the cruises of the ITALIANTARTIDE project was carried out, is classified as a coastal and continental shelf zone (CCSZ), in which the dynamics of nutrients and phytoplankton are largely controlled by a hydrological structure and irradiance regime (Smetacek and Passow, 1990; Nelson and Smith, 1991). Typical CCSZ phenomena are the marginal ice zones (MIZ), where some consistency in enhanced vertical stability has been observed following the input of less saline and less dense meltwater, together with nutrient depletion and biogenic matter production (El-Sayed and Taguchi, 1981; Smith and Nelson, 1985; Nelson et al., 1987, 1989; Cota et al., 1992). Therefore, particularly in the MIZ, pycnocline strengthening shows its double effect: it decreases phytoplankton dispersal by vertical mixing and, in a situation characterised by lower nutrient concentrations, it increases phytoplankton buoyancy in the photic layer (Culver and Smith, 1989). During the phytoplankton bloom at the ice edge, the concentration of particulate organic matter increases (Smith and Nelson, 1985) and its biochemical composition changes (Fabiano et al., 1993).

The aim of this study was to investigate the relationships between pycnocline strengthening, which occurs in the MIZ, nutrient removal due to primary production, and the amount and biochemical composition of the particulate organic matter.

\section{METHODS}

\section{Cruises}

As part of the ITALIANTARTIDE Polar Research Project, two oceanographic cruises were carried out during the austral summers of 1987-88 and 1989-90. In the first cruise (on the M.S. Polar Queen), from 5 January to 14 February, sampling was concentrated in the area of Terra Nova Bay and along a transect $120 \mathrm{~nm}$ eastwards in the Ross Sea (Fig. 1A). The second cruise consisted of two legs. The first leg (on the R.V. Cariboo) took place from 5 December to 6 January and covered the areas of Balleny Islands, the Ross Shelf continental margin eastwards from Cape Adare, and a transect in the Ross Sea at the same latitude sampled during the 1987-88 cruise (Fig. 1B). The second leg (on the R.V. Malippo), was conducted from 13 January to 2 February and sampled along the coast (ca $100-150 \mathrm{~m}$ offshore) from Evans Cove to Campbell Ice Tongue, at Terra Nova Bay (Fig. 1C).

Following the classification for nutrient and phytoplankton dynamics (Treguer and Jacques, 1992), the investigated areas mainly belong to the coastal and continental shelf zone (CCSZ). In addition, depending on the period in which they were operating and on their location, some stations were typical of a MIZ in massive melting phase, while others had features typical of areas sometimes free of sea-ice. 

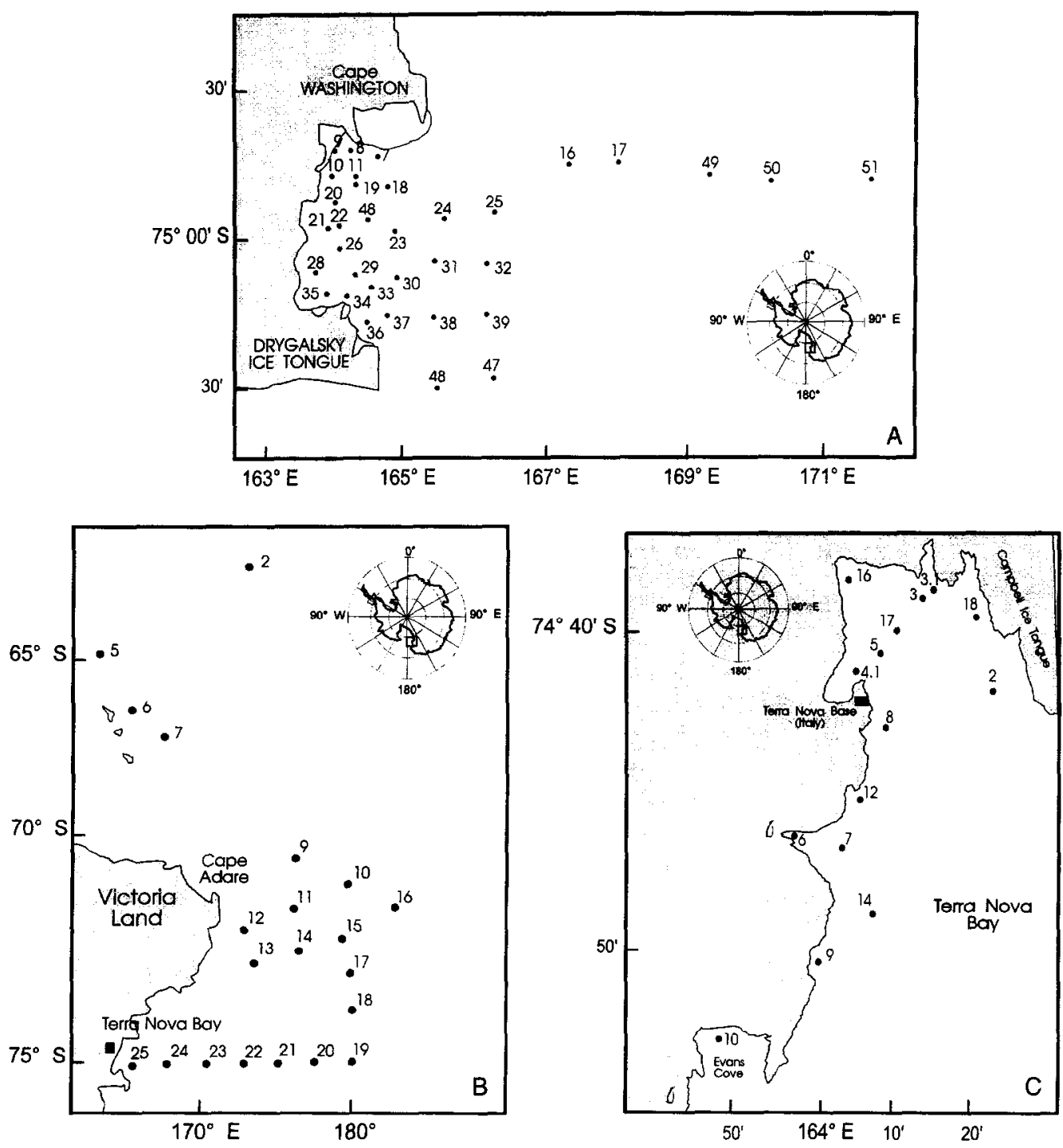

Fig. 1. Study area and sampling stations. (A) Polar Queen cruise (from January 5 to February 14), (B) Cariboo cruise (from December 5 to January 6) and (C) Malippo cruise (from January 13 to February 2).

\section{Sampling}

Water sampling was carried out by means of 101 Niskin bottles assembled in a rosettesampler or mounted on hydrological wire. The only sample of "so defined $0 \mathrm{~m}$ " was taken by means of a spigot-fitted bucket. In the upper $200 \mathrm{~m}$, standard sampling depths were the surface, $10,25,50,100$ and $200 \mathrm{~m}$. Moreover, variable depths were added to the hydrological casts according to the stratification and the attenuation of incident radiation. Following these criteria the number of sampling depths in the upper $200 \mathrm{~m}$ ranged from a 
minimum of six to a maximum of 13 . Samples for particulate organic matter concentration were collected only during the 1989-90 cruise.

\section{Methodologies and instruments}

The hydrological casts were supported by a CTD vertical profile recorded with either an EG \& G Mk3 or a ME mod. KMS probe. Temperature and depth readings were checked by means of analogic or SIS digital reversing thermometers and pressure meters placed on the Niskin bottles. At the same time, salinity samples were collected at discrete depths to compare continuous vertical profiles with the values determined by an Autosal 8400 Guildline or a Minisal 2001 AGE salinometer. Chemical analyses for nutrient concentrations were carried out onboard after filtration on Whatman GF/C filters (Hansen and Grasshoff, 1983) and using a Technicon II AutoAnalyzer.

In the two legs of the second cruise only, water samples (0.5-2.0 l) for the determination of particulate organic matter concentration were pre-filtered through $200 \mathrm{~mm}$ mesh net and then filtered onto Nuclepore filters $(0.4 \mathrm{~mm}$ pore size) for particulate protein (PPRT) and particulate carbohydrate (PCHO) analyses, or onto GF/C Whatman filters (precombusted at $450^{\circ} \mathrm{C}$ ) for organic carbon (POC) and nitrogen (PON). After filtration, the filters were immediately stored at $-20^{\circ} \mathrm{C}$. Replicates were not routinely collected. However, a series of replicate samples was collected from surface water of Terra Nova Bay to ascertain the coefficient of variation (CV) for the various measurements. CVs were $2.3 \%$ for $\mathrm{POC}, 2.7 \%$ for PON, $11 \%$ for PCHO and $3.2 \%$ for PPRT.

The analysis of particulate organic matter biochemical components was carried out using a Varian 635 spectrophotometer. Particulate carbohydrates were measured according to Dubois et al. (1956), using $\mathrm{D}(+)$-glucose as a standard, and particulate proteins were assessed according to Hartree (1972), using bovine albumine solutions as a standard. After removal of carbonates by $\mathrm{HCl}$ vapors in a desiccator (Hedges and Stern, 1984; Tanoue, 1985), particulate organic carbon and nitrogen were analysed by combustion using a CHNS-O EA 1108 elemental analyser (Carlo Erba). Cyclohexanone was used as a standard.

Data on positions, dates, sampling depths and values of the parameters measured are reported in Boldrin and Stocchino (1990), Catalano and Benedetti (1990), Fabiano et al. (1991a,b,c, 1992), Catalano et al. (1991a,b) and Artegiani et al. (1992).

\section{RESULTS AND DISCUSSION}

In order to obtain an estimate of the nutrient anomalies, due to the phytoplankton assimilation, found in the upper mixed layer (UML), the following assumptions are made:

(1) The vertical stability $E$ according to Steinhorn (1985):

$$
E=\rho^{-1}(\partial \rho / \partial z)
$$

where $\rho$ is the density of the seawater and $z$ is the depth in $\mathrm{m}$, is used to estimate both the strength of the pycnocline and the lower limit of the mixed layer.

(2) The summer formation of the UML, which in the Ross Sea usually occurs within the upper $100 \mathrm{~m}$, is considered to be due to solar heating or to the salinity decrease originating from the pack-ice melting or to both these factors.

(3) The salinity and nutrient concentrations determined at the depth immediately below 
the UML, hereafter called $Z(\mathrm{~L})$, are taken as reference values for the winter prior to dilution by the advection of summer ice-meltwater or utilisation by phytoplankton.

(4) In the upper $100 \mathrm{~m}$, all the depths are expressed in dbar in place of $\mathrm{m}$.

The method suggested by Mitchell and Holm-Hansen (1991) has therefore been followed to establish the strength of the pycnocline between the UML and the already defined depth $Z$ (L) immediately below it. First, $E$ was calculated for every depth, $Z$, between 0 and $100 \mathrm{dbar}$ from the following equation:

$$
E(Z)=\rho^{-1} \times\left[\gamma_{T(Z+\Delta Z / 2)}-\gamma_{T(Z-\Delta Z / 2)}\right] / \Delta Z
$$

where $\rho$ and $\gamma$ are, respectively, the seawater density, expressed in $\mathrm{kg} \mathrm{dm}^{-3}$, and the density anomaly (UNESCO, 1985), $T$ is the temperature in ${ }^{\circ} \mathrm{C}, Z$ is the depth in dbar and $\Delta Z$ is a selected depth interval (4 dbar in our case).

Then, at every station, the vertical profile of $E(Z)$ can be reconstructed and, from this, one can find the maximum value of $E$ and the corresponding depth $Z(\mathrm{UML})$. Finally $Z(\mathrm{~L})$, which is the first depth below $Z(\mathrm{UML})$ where $E(Z)$ becomes low and again nearly constant, can be deduced from the same profile (Fig. 2).

Summarising, $Z(\mathrm{UML})$ is the depth corresponding to the maximum density gradient, which also corresponds approximately to the middle of the pycnocline; here $E$ reaches its

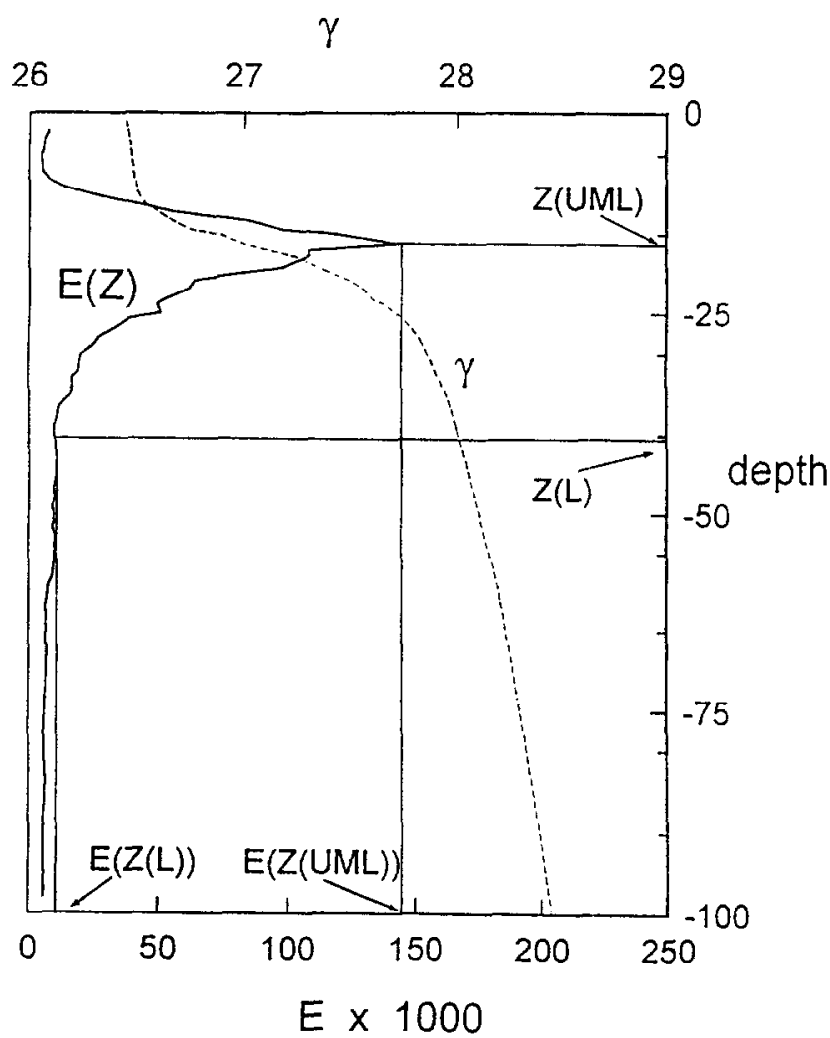

Fig. 2. Vertical profile of the stability $E\left(\mathrm{~m}^{-1} \times 1000\right)$ and density anomaly $\gamma\left(\mathrm{kg} \mathrm{m}^{-3}\right)$. 
maximum value, which is also taken as a stability index of the mixed layer (i.e. what we have called pycnocline strength). $Z(\mathrm{~L})$, on the other hand, is assumed to be the depth of the base of the pycnocline, corresponding to the top of the winter water and considered to be unaffected by the summer dilution or phytoplankton assimilation (Catalano and Benedetti, 1990; Catalano et al., 1991a,b; Fabiano et al., 1993). The values of all the parameters calculated for the three cruises are reported in Table 1.

From these considerations on vertical stability and from the consequent reduction in vertical mixing, the weighted average consumption of nutrients [nitrate $(\Delta N W)$, phosphate $(\Delta \mathrm{PW})$ and silicate $(\Delta \mathrm{SiW})$, in $\left.\mathrm{mmol} \mathrm{m}^{-3}\right]$ in the UML can be calculated. Of course, the higher the $E$ value at the $Z(U M L)$ depth the more reliable the estimate will be. To calculate nutrient consumption, nutrient concentrations were first integrated between the surface and $Z(L)$ and the result divided by $Z(L)$, thus giving a weighted average concentration of each nutrient in the UML. Nutrient concentrations at the exact $Z(\mathrm{~L})$ depth were calculated by linear interpolation between the values found at the two closest depths; these were then assumed to be equal to the theoretical average nutrient concentrations, constant in the whole UML, which are considered to be the memory of the winter water unaffected by meltwater dilution or by phytoplankton assimilation. This assumption is justified by the vertical profiles of nutrients in the UML of several stations where only a very weak stratification was observed (Catalano and Benedetti, 1990; Catalano et al., 1991a,b).

Assuming an average sea-ice salinity of 6 (Ackley et al., 1979), and an average nutrient content in the sea-ice according to Dieckmann et al. (1991), nutrient concentration decreases resulting only from dilution by meltwater can be calculated from the average salinity measured in the UML. From the difference between the "diluted" nutrient value and the weighted mean calculated on the basis of the integrated value in the UML, nutrient utilisation was determined for each station. Particulate organic matter concentrations for some stations are listed in Table 2.

Figure 3 shows the dependence of estimated nutrient depletion on pycnocline strength. Despite the differences in sampling periods and sites, it is clear that for $E(Z(U M L)) \leq 25$, the increments of utilised nitrate, phosphate and silicate are higher than those for $E(Z(\mathrm{UML}))>25$ (Table 3). Furthermore, for $E(Z(\mathrm{UML}))>25$, nutrient utilisation ratios are more independent of $E(Z(\mathrm{UML})$ ) (Table 3$)$. In summary, $49 \%$ of the stations are characterised by $E(Z(\mathrm{UML}))>25$ and show prevalently a depletion of nutrients of $\geq 4,0.4$ and $10 \mathrm{mmol} \mathrm{m} \mathrm{m}^{-3}$ for nitrate, phosphate and silicate, respectively.

Since salinity contributes approximately 10 times more than temperature to determining density values, $E(Z(\mathrm{UML}))>25$ values are mostly due to the presence of meltwater originating from the ice-edge. Only in a few cases could surface heating have been intense enough to give significant thermal stratification; even in those cases, however, its contribution to density never equalled that of salt dilution.

Considering the nutrient depletion and primary production relationship (Jennings et al., 1984; Sambrotto et al., 1986), the increase of particulate organic matter and the large variations observed in biochemical composition during the algal bloom (Smetacek and Hendrikson, 1979; Parsons et al., 1984; Tanoue, 1985; Fabiano et al., 1993), we have examined correlations of nutrient consumption ( $\Delta \mathrm{NW}, \triangle \mathrm{PW}$ and $\Delta \mathrm{SiW}$ ) with $\mathrm{POC}$ concentrations and with the PPRT/PCHO ratio, which is an expression of suspended matter biochemical composition and, to a certain extent, its "age" (Cauwet, 1978; Moal et al., 1987). Significant correlations between nutrient consumption and both POC concentrations and the PPRT/PCHO ratio were found (Table 3). It is interesting to note 


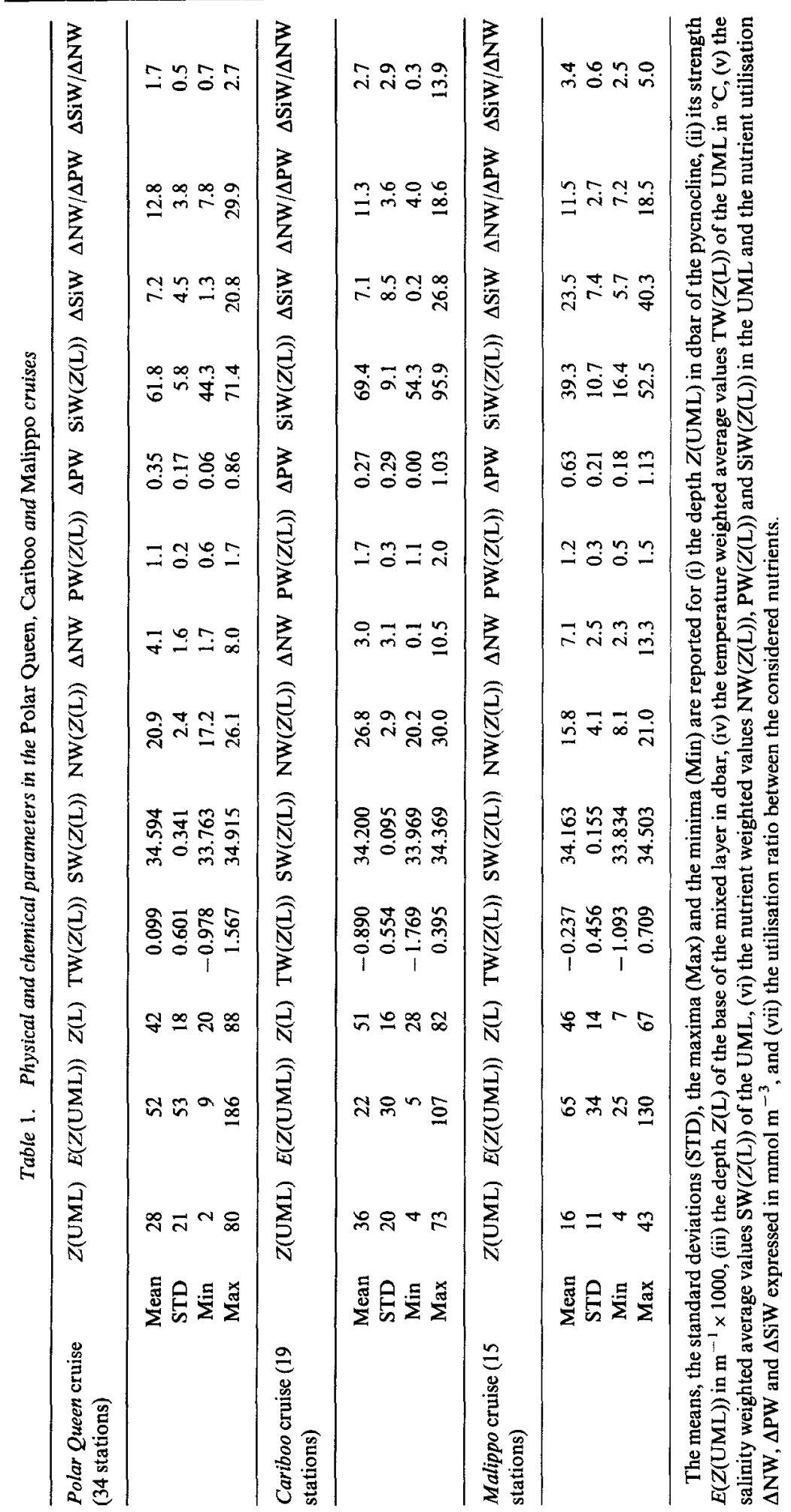


Table 2. Chemical and particulate matter parameters at stations where there was sampling of suspended matter: index of vertical stability $\left[\mathrm{E}(\mathrm{Z}(U M L))\right.$ in $\left.\Delta \mathrm{\gamma m}^{-1} \times 1000\right]$, nutrient utilisation $(\Delta N W, \Delta P W$ and $\Delta S i W$ in $\mathrm{mmol} \mathrm{m}{ }^{-3}$ ), particulate organic matter (POC in $\mu \mathrm{g}^{-1}$ ), PPRT/PCHO and $C / N$ ratio

\begin{tabular}{cccccccccccc}
\hline & Station & $E(Z(\mathrm{UML}))$ & $\Delta \mathrm{NW}$ & $\Delta \mathrm{PW}$ & $\Delta \mathrm{SiW}$ & $\begin{array}{c}\Delta \mathrm{NW} / \\
\Delta \mathrm{PW}\end{array}$ & $\Delta \mathrm{SiW} / \Delta \mathrm{NW}$ & POC & $\begin{array}{c}\text { PPRT/ } \\
\text { PCHO }\end{array}$ & $\mathrm{C} / \mathrm{N}$ \\
\hline Cariboo cruise & 5 & 15 & 3.5 & 0.33 & 0.9 & 10.6 & 0.3 & 340.5 & 1.4 & 6.8 \\
& 10 & 6 & 1.3 & 0.12 & 0.3 & 10.8 & 0.3 & 125.5 & 0.6 & 7.5 \\
& 15 & 6 & 1.2 & 0.09 & 1.8 & 12.8 & 1.5 & 93.2 & 1.3 & 7.0 \\
& 17 & 7 & 2.2 & 0.17 & 7.4 & 13.3 & 3.4 & 109.2 & 1.8 & 6.5 \\
& 19 & 9 & 2.2 & 0.19 & 5.6 & 11.1 & 2.6 & 130.3 & 1.3 & 6.9 \\
& 21 & 7 & 1.2 & 0.09 & 2.1 & 12.8 & 1.7 & 104.1 & 2.0 & 5.9 \\
& 23 & 61 & 4.9 & 0.67 & 17.8 & 7.4 & 3.6 & 316.9 & 1.9 & 6.0 \\
& 25 & 107 & 7.2 & 0.73 & 23.4 & 9.8 & 3.3 & 360.3 & 2.5 & 5.5 \\
Malippo cruise & 2 & 128 & 13.3 & 1.13 & 40.3 & 11.7 & 3.0 & 362.9 & 2.9 & 5.5 \\
& 3 & 62 & 6.1 & 0.33 & 25.2 & 18.5 & 4.1 & 225.4 & 2.5 & 5.7 \\
& 4.1 & 33 & 4.9 & 0.59 & 18.8 & 8.3 & 3.8 & 161.4 & 2.1 & 5.9 \\
& 5 & 95 & 9.1 & 0.78 & 29.3 & 11.7 & 3.2 & 218.9 & 2.8 & 5.7 \\
6 & 40 & 7.3 & 0.60 & 21.7 & 12.2 & 3.0 & 179.7 & 2.8 & 5.7 \\
& 7 & 130 & 7.4 & 0.85 & 27.1 & 8.7 & 3.7 & 177.5 & 3.0 & 6.4 \\
8 & 65 & 7.0 & 0.63 & 25.6 & 11.2 & 3.7 & 259.3 & 2.1 & 5.9 \\
& 9 & 90 & 6.4 & 0.63 & 20.1 & 10.2 & 3.1 & 252.5 & 1.7 & 5.5 \\
& 10 & 33 & 2.3 & 0.18 & 5.7 & 12.5 & 2.5 & 219.1 & ND & 5.4 \\
12 & 54 & 6.9 & 0.59 & 23.2 & 11.7 & 3.4 & 197.0 & 2.2 & 5.7 \\
14 & 43 & 6.9 & 0.60 & 21.6 & 11.5 & 3.1 & 190.9 & 2.2 & 5.6 \\
16 & 25 & 7.5 & 0.61 & 22.2 & 12.3 & 3.0 & 258.4 & ND & 6.2 \\
17 & 84 & 4.2 & 0.59 & 21.1 & 7.2 & 5.0 & 234.2 & 1.9 & 6.8 \\
18 & 45 & 7.4 & 0.73 & 20.4 & 10.1 & 2.8 & 157.1 & 2.2 & 6.8 \\
\hline
\end{tabular}

$\mathrm{ND}=$ not determined

that, using the consumption values as previously calculated at $E(Z(\mathrm{UML}))=25$ as an "arbitrary threshold", stations can be divided into two groups according to the content and biochemical composition of the particulate organic matter (Figs 4 and 5). The first group includes stations close to the coast and with a strong vertical stratification induced by icemelting (average value $E(Z(\mathrm{UML}))=71$ ). They are characterised by greater nutrient utilisation (average value $=7.1,0.7$ and $23.6 \mathrm{mmol} \mathrm{m}^{-3}$ for $\Delta \mathrm{NW}, \Delta \mathrm{PW}$ and $\Delta \mathrm{SiW}$, respectively), a high biomass (average value $\mathrm{POC}=230 \mu \mathrm{g}^{-1}$ ) and high PPRT/PCHO ratio (2.2), typical of fresh particulate organic matter of autotrophic origin (Fabiano et al., 1993).

The time elapsed to produce the observed nutrient depletion can be calculated from data on primary productivity measured by the ${ }^{14} \mathrm{C}$ technique. Using a $\mathrm{C} / \mathrm{N}$ ratio equal to 5.6 (Jennings et al., 1984; Fabiano et al., 1993) for Southern Ocean phytoplankton, the estimated nitrogen depletion at stations 5, 2 and 4.1 (Malippo cruise) was converted to carbon assimilation, yielding 51,75 and $28 \mathrm{mmol} \mathrm{m}^{-3}$, respectively. These values, when compared with the daily integrated $\mathrm{C}$ uptake measured at two stations near ours (Saggiomo ct al., 1992), imply that the estimated depletion required 22 days for Sta. 5, 24 days for Sta. 2 and 21 days for Sta. 4.1. Taking into account the dates of sampling at these stations, 13 January 1990, 15 January 1990 and 31 January 1990, respectively, this indicates an active period of sea-ice melting at Terra Nova Bay from about 22 December to 10 January. Although this estimate is rather rough, neglecting other factors such as the lateral advection, 

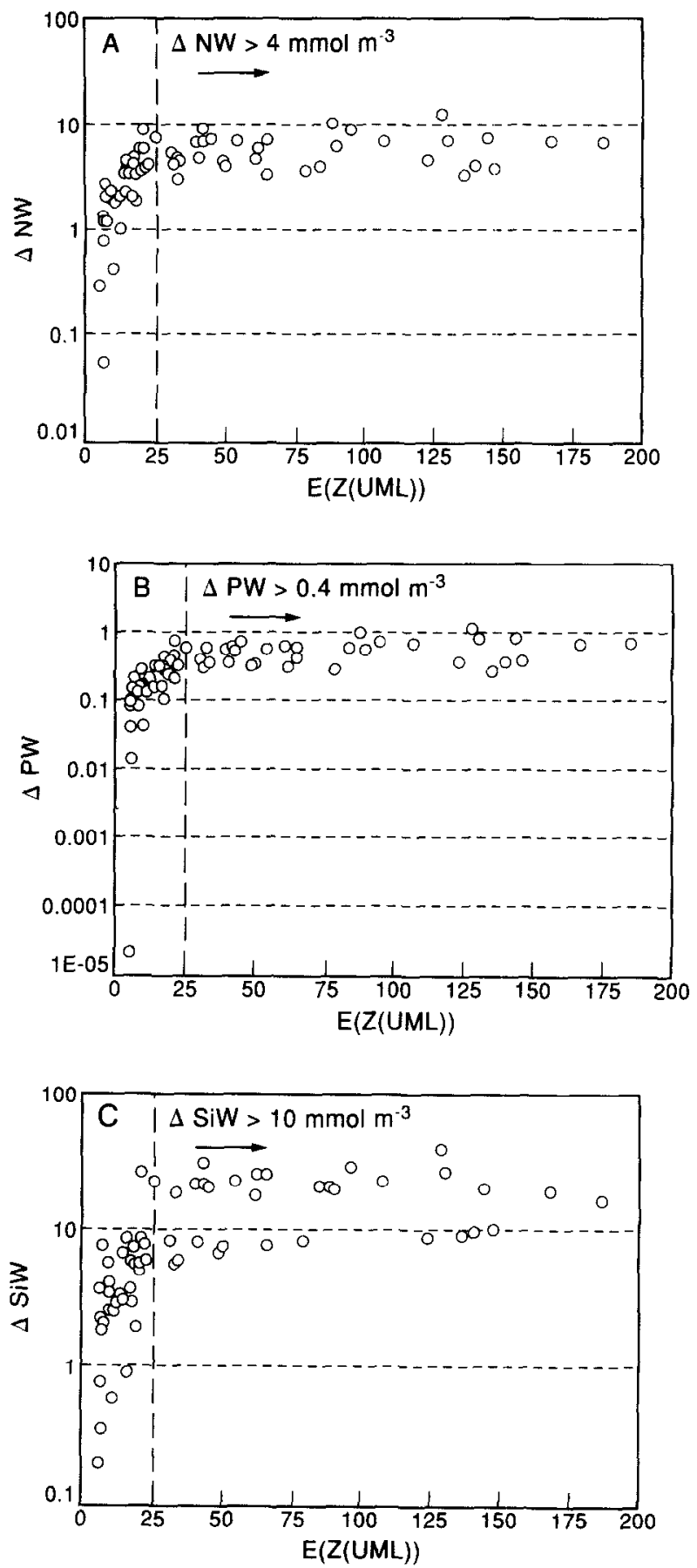

Fig. 3. Nutrient utilisation $\left(\mathrm{mmol} \mathrm{m}^{-3}\right)$ : (A) nitrate $(\Delta \mathrm{NW}),(B)$ phosphate $(\Delta \mathrm{PW})$ and $(C)$ silicate ( $\Delta \mathrm{SiW})$ vs the vertical stability $E\left(\mathrm{~m}^{-1} \times 1000\right)$. The dashed vertical line represents the "threshold" for $E\left(Z(\mathrm{UML})=25\right.$. Above this value the nutrient utilisation is prevalently $\geq 4,0.4$ and $10 \mathrm{mmol} \mathrm{m}^{-3}$ for nitrate, phosphate and silicate, respectively. 
Table 3. Parameters for the linear regressions between POC $\left(\mu \mathrm{g}^{-1}\right)$ and PPRT/PCHO ratio, nutrient depletion $\left(\triangle N W, \Delta P W\right.$ and $\triangle S i W$ in $\left.\mathrm{mmol} \mathrm{m}^{-3}\right)$ and $\mathrm{E}(\mathrm{Z}(U M L))$

\begin{tabular}{lcccccc}
\hline$X$ & $Y$ & Slope & Constant & $d f$ & $r$ & $p$ \\
\hline$E(Z(\mathrm{UML})) \leq 25$ & $\Delta \mathrm{NW}$ & $2.8 \times 10^{-1}$ & $-7.8 \times 10^{-1}$ & 32 & 0.80 & $<0.001$ \\
$E(Z(\mathrm{UML})) \leq 25$ & $\Delta \mathrm{PW}$ & $2.0 \times 10^{-2}$ & $-2.7 \times 10^{-2}$ & 32 & 0.74 & $<0.001$ \\
$E(Z(\mathrm{UML})) \leq 25$ & $\Delta \mathrm{SiW}$ & $5.3 \times 10^{-1}$ & -1.7 & 32 & 0.57 & $<0.01$ \\
$E(Z(\mathrm{UML}))>25$ & $\Delta \mathrm{NW}$ & $1.6 \times 10^{-2}$ & 4.6 & 32 & 0.31 & $<0.1$ \\
$E(Z(\mathrm{UML}))>25$ & $\Delta \mathrm{PW}$ & $2.4 \times 10^{-3}$ & $3.5 \times 10^{-1}$ & 32 & 0.45 & $<0.01$ \\
$E(Z(\mathrm{UML}))>25$ & $\Delta \mathrm{SiW}$ & $5.6 \times 10^{-2}$ & 11.8 & 32 & 0.27 & $<0.5$ \\
$\Delta \mathrm{NW}$ & $\mathrm{POC}$ & 15.6 & 127.0 & 20 & 0.58 & $<0.01$ \\
$\Delta \mathrm{PW}$ & POC & 174.6 & 123.3 & 20 & 0.60 & $<0.01$ \\
$\Delta \mathrm{SiW}$ & POC & 3.8 & 147.3 & 20 & 0.50 & $<0.05$ \\
$\Delta \mathrm{NW}$ & PPRT/PCHO & 0.2 & 1.2 & 18 & 0.79 & $<0.001$ \\
$\Delta \mathrm{PW}$ & PPRT/PCHO & 1.6 & 1.2 & 18 & 0.75 & $<0.001$ \\
$\Delta \mathrm{SiW}$ & PPRT/PCHO & 0.05 & 1.3 & 18 & 0.84 & $<0.001$ \\
\hline
\end{tabular}

$X$, independent variable; $Y$, dependent variable; $d f$, degrees of freedom; $r$, coefficient of regression; $p$, probability level.

the diffusion from subsurface layers, the recycling of nutrients and therefore the regenerated production, it agrees well with the observations carried out in the field at that time. It should be interesting to determine whether these estimated times are consistent with the time-scale of persistence of an upper stratification at Terra Nova Bay in summer. However, the hydrological data of Innamorati et al. (1991) suggest a constant presence of a surface stratification (10-40 $\mathrm{m}$ thick) from 4 January until 1 February, characterised by a salinity decrease ranging between 0.5 and 1.0 .

The second group of mainly pelagic stations is characterised by low $E(Z(\mathrm{UML}))$ values (average value $=10$ ), low nutrient utilisation (average values of $2.0,0.17$ and $3.4 \mathrm{mmol} \mathrm{m}^{-3}$ for $\Delta \mathrm{NW}, \Delta \mathrm{PW}$ and $\Delta \mathrm{SiW}$, respectively) and lower biomass (average value of $\left.\mathrm{POC}=160 \mu \mathrm{gl}^{-1}\right)$, with particulate matter mostly detritital $(\mathrm{PPRT} / \mathrm{PCHO}=1.2)$. These results are also confirmed by Fabiano et al. (1993) who reported a high POC/Chl $a$ ratio, exceeding 150 , and a high $\mathrm{C} / \mathrm{N}$ ratio for stations of the second group, and lower $\mathrm{POC} / \mathrm{Chl} a$ (around 100) and $\mathrm{C} / \mathrm{N}$ ratios for stations of the first group (Fabiano et al., 1993). It is well known that high POC/Chl $a$ and $\mathrm{C} / \mathrm{N}$ ratios are typical of organic matter with a higher detrital or heterotrophic component, which are characteristically associated with primary production processes in late summer and autumn (Holm-Hansen et al., 1989; Nelson et al., 1989; Treguer et al., 1990).

\section{FINAL CONSIDERATIONS}

In conclusion, two additional considerations can be drawn from our results. First, it can be seen from Table 1 that the N/P ratios are lower than the expected value of 16 (Redfield $e t$ al., 1963), while $\mathrm{Si} / \mathrm{N}$ ratios are higher than the value of 1 proposed by Richards (1958) for the Atlantic intermediate layer and the value of 0.1 deduced, after Copin-Montegut and Copin-Montegut (1978), for the Indian subantarctic area. Similar features have been found already for the southernmost province of the Southern Ocean. In particular, CopinMontegut and Copin-Montegut (1978), analysing the particulate matter from the Antarctic 

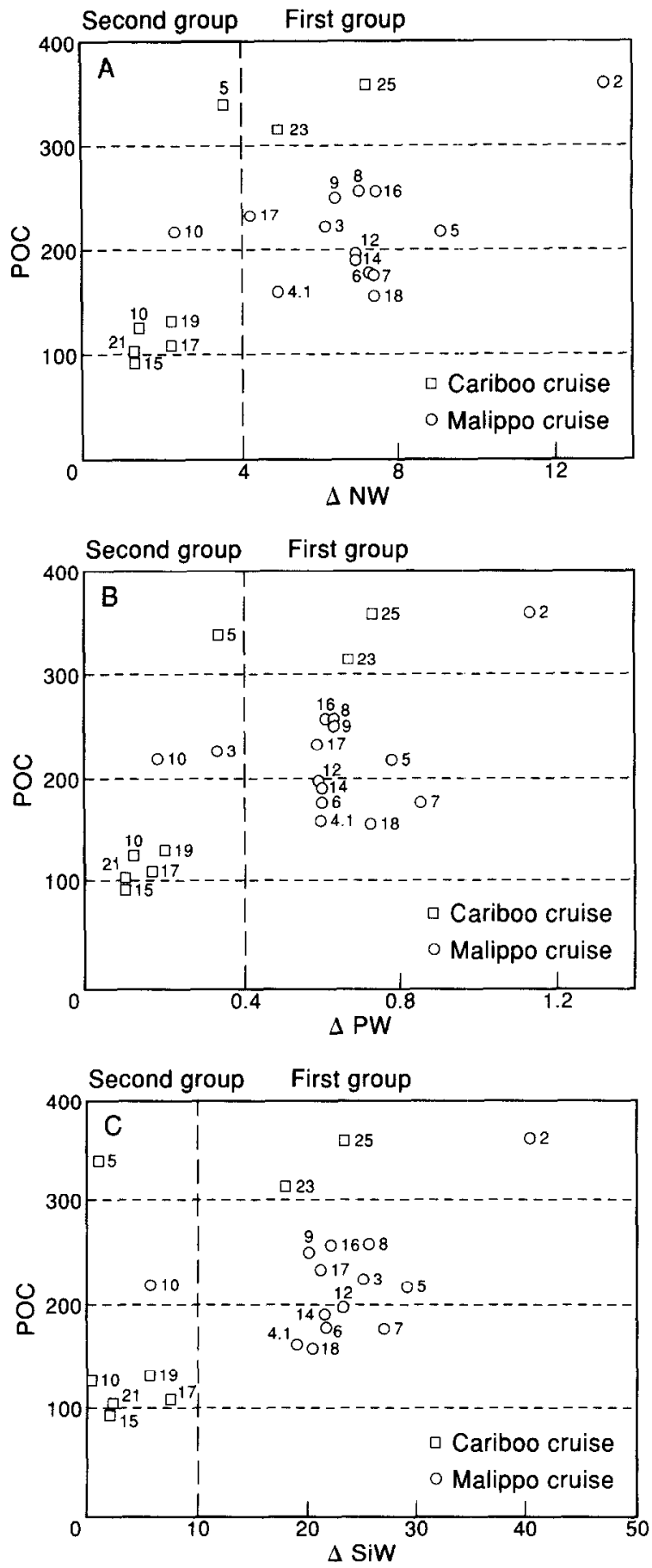

Fig. 4. Comparison of $P O C\left(\mu g ~^{-1}\right)$ with nutrient consumption in $\mathrm{mmol} \mathrm{m}^{-3}$. (A) Nitrate $(\Delta \mathrm{NW})$, $(B)$ phosphate $(\Delta \mathrm{PW})$ and $(C)$ silicate $(\Delta \mathrm{SiW})$. The dashed vertical line represents the "threshold" for the nutrient utilisation calculated at $E(Z(U M L))=25$. The stations are identified by their numbers. 

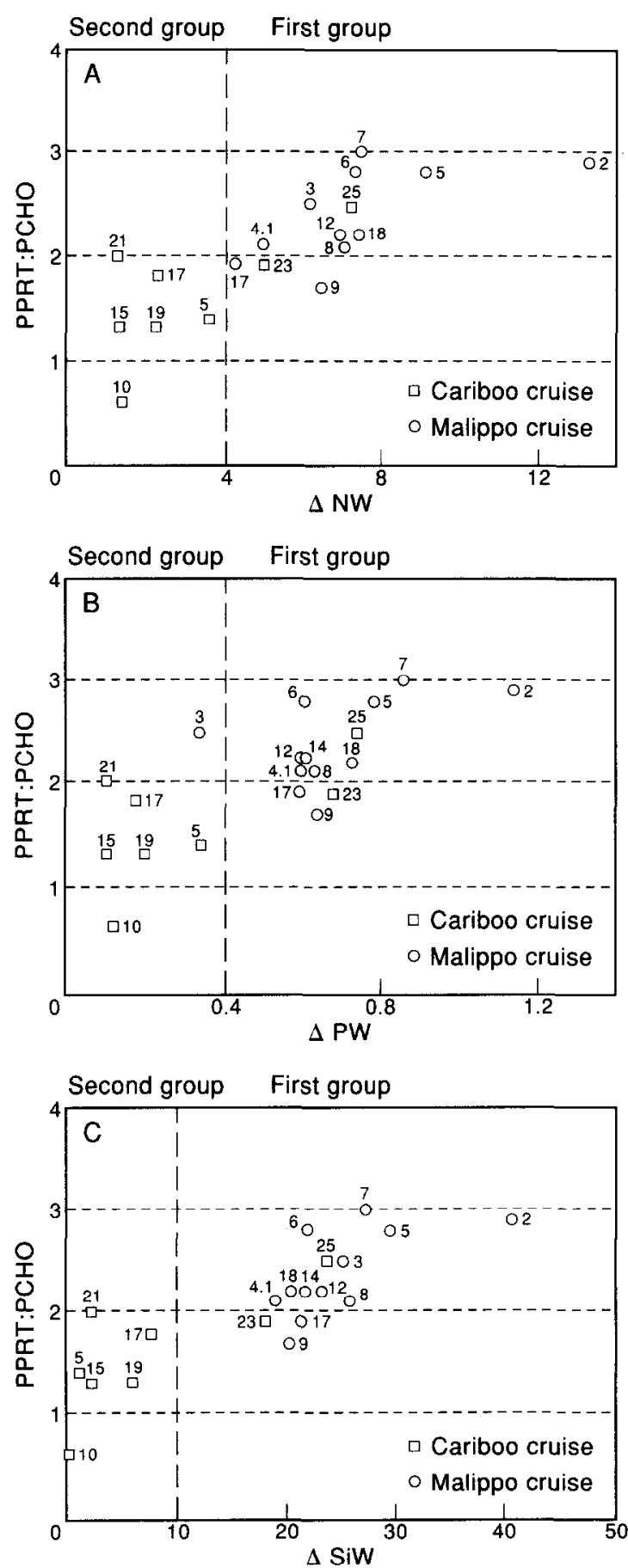

Fig. 5. Comparison of PPRT/PCHO ratios with nutrient consumption in mmol m $\mathrm{m}^{-3}$. (A) Nitrate $(\Delta N W),(B)$ phosphate $(\Delta \mathrm{PW})$ and $(\mathrm{C})$ silicate $(\Delta \mathrm{SiW})$. The dashed vertical line represents the "threshold" for nutrient utilisation calculated at $E(Z(U M L))=25$. The stations are identified by their numbers. 
Ocean, found $\mathrm{N} / \mathrm{P}$ and $\mathrm{Si} / \mathrm{N}$ ratios ranging, respectively, from 8.9 to 17.1 and from 0.1 to 2.3. They attributed these values on the one hand to a greater ability of Antarctic phytoplankton to incorporate phosphorus in its "energy cycle" (e.g. ATP and ADP) and, on the other, to the diatom-dominated phytoplankton blooms. In contrast, Zentara and Kamykowski (1981) determined in the Ross Sea $\left(77^{\circ} \mathrm{S}\right.$ and $\left.168^{\circ} \mathrm{E}\right)$ an $\mathrm{Si} / \mathrm{N}$ ratio around 0.4 with a coupled potential nitrate limitation for the phytoplankton growth. Our data confirm neither this low value for the $\mathrm{Si} / \mathrm{N}$ ratio nor the potential nitrate limitation, this being attributed rather to silicon, on the basis of dissolved $\mathrm{NO}_{3}$ and $\mathrm{Si}(\mathrm{OH})_{4}$ values (Catalano and Benedetti, 1990; Catalano et al., 1991a,b). El-Sayed and Taguchi (1981), Jennings et al. (1984) and Le Jehan and Treguer (1985) observed different values all ranging, however, between 9.5 and 12 for $\mathrm{N} / \mathrm{P}$ and between 0.8 and 4 for $\mathrm{Si} / \mathrm{N}$. This variability of the ratios is attributed to the increased utilisation of phosphorus with respect to nitrogen, to the incidence of "regenerated" production and of the preferential assimilation of ammonium, as high as $70 \%$ of the total productivity, and to the high demand of diatoms for silicate. The uncoupling of nitrogen and silicon cycles is still mentioned by Treguer and Jacques (1992) to explain the difference in the removal of silicon from surface layers with respect to carbon and nitrogen. Nelson and Smith (1986) stress that, in the Ross Sea, whereas the depletion of dissolved silicic acid at the ice-edge is matched almost exactly by the accumulation of biogenic particulate silica, the particulate nitrogen accumulation accounts for less than half of the observed nitrate depletion.

Reconsidering now the ratios reported in Table 1, it is possible to see that $\mathbf{N} / \mathbf{P}$ values for the three cruises are fairly constant and in good agreement with the values proposed for Antarctic phytoplankton, while the $\mathrm{Si} / \mathrm{N}$ ratios vary from 1.7 to 3.4. Taking into account the previous considerations, from Table 2 and Figs 4 and 5 , it can be observed that the higher $\mathrm{Si}$ / $\mathrm{N}$ ratios are found mostly at stations characterised by a more stratified water column with higher utilisation of nitrogen and silicon, high PPRT/PCHO and high biomass typical of fresh particulate organic matter of autotrophic origin.

In addition, our results are in agreement with an "evolution" model of phytoplankton blooms in pelagic Antarctic waters (Jacques, 1991; Smetacek et al., 1992; Treguer and Jacques, 1992; Fabiano et al., 1993; Hecq et al., 1993). Moreover, we can state that the vertical stability index, expressed as $E(Z(\mathrm{UML}))$, and the calculated nutrient utilisation can be used as discriminating criteria to characterise the different phases of the primary production process. The value of vertical stability, $E(Z(U M L))=25$, represents a threshold for the primary production process. Below this value the significant relationship between vertical stability and nutrient consumption indicates that the vertical stability of the water column is the main factor influencing primary production. Above this value, nutrient depletion and high biomass (POC concentrations), with little dependence on $E(Z(U M L)$ ), show that other factors, such as grazing pressure (Smetacek, 1985; Huntley et al., 1991), light limitation (Smetacek and Passow, 1990; Nelson and Smith, 1991) and micronutrient availability (Martin and Fitzwater, 1988; Martin et al., 1990), may play a major role in regulating primary productivity in the upper mixed layer of Antarctic water.

Acknowledgements-We are grateful to Professor Walker O. Smith for valuable discussions, comments and suggestions, and to Dr Antonio Artegiani and Dr Elio Paschini for the temperature and salinity data. We are grateful to Rossella Bruzzone and Massimo Iorio for technical assistance. The authors are indebted to Professor Letterio Guglielmo, co-ordinator of the Oceanography Programme, and to the scientific staff of the Project who contributed to the analysis of the data with several suggestions and comments. This study was supported by the National Scientific Commission for Antarctica of the Italian Government. 


\section{REFERENCES}

Ackley S. F., K. A. Buck and S. Taguchi (1979) Standing crop of algae in the sea-ice of Weddell Sea region. DeepSea Research, 26, 269-281.

Artegiani A., R. Azzolini, E. Paschini and S. Creazzo (1992) Physical oceanographic conditions in the southern Pacific Ocean and in the western Ross Sea. In: National Scientific Commission for Antarctica, Oceanographic Campaign 1989-90. Data report II, pp. 5-62.

Boldrin A. and C. Stocchino (1990) On the hydrological characteristics of Terra Nova Bay (Ross SeaAntarctica). In: National Scientific Commission for Antarctica, Oceanographic Campaign 1987-88. Data report I, pp. 11-57.

Catalano G. and F. Benedetti (1990) Distributions of nutrients in the Terra Nova Bay and in the Ross Sea. In: National Scientific Commission for Antarctica, Oceanographic Campaign 1987-88. Data report I, pp. 6183.

Catalano G., F. Benedetti, A. Goffart and M. Iorio (1991a) Distribution of dissolved oxygen, pH, total alkalinity and nutrients in Southern Ocean and Ross Sea (R.V. Cariboo 1989-90 cruise). In: National Scientific Commission for Antarctica, Oceanographic Campaign 1989-90. Data report I, pp. 11-23.

Catalano G., F. Benedetti and M. Iorio (1991b) Coastal oceanography from Cape Russel to Campbell Ice Tongue (Terra Nova Bay). Dissolved oxygen, nutrients, $\mathrm{pH}$, total alkalinity and total inorganic carbon distribution. In: National Scientific Commission for Antarctica, Oceanographic Campaign 1989-90. Data report I, pp. 25-32.

Cauwet G. (1978) Organic chemistry of seawater particulates concepts and developments. Oceanologica Acta, 1, $99-105$.

Copin-Montegut C. and G. Copin-Montegut (1978) The chemistry of particulate matter from the south Indian and Antarctic Oceans. Deep-Sea Research, 25, 911-931.

Cota G. F., W. O. Smith, D. M. Nelson, R. D. Muench and L. I. Gordon (1992) Nutrient and biogenic particulate distributions, primary productivity and nitrogen uptake in the Weddell-Scotia Sea marginal ice zone during winter. Journal of Marine Research, 50, 155-181.

Culver M. E. and W. O. Smith (1989) Effects of environmental variation on sinking rates of marine phytoplankton. Journal of Phycology, 25, 262-270.

Dieckmann G. S., M. A. Lange, S. F. Ackley and J. C. Jennings (1991) The nutrient status in the sea-ice of the Weddell Sea during winter: effects of sea-ice texture and algae. Polar Biology, 11, 449-456.

Dubois M., K. Gilles, J. K. Hamilton, P. A. Rebers and F. Smith (1956) Colorimetric method for determination of sugars and related substances. Analytical Chemistry, 28, 350-356.

El-Sayed S. Z. and S. Taguchi (1981) Primary production and standing crop of phytoplankton along the ice-edge in the Weddell Sea. Deep-Sea Research, 28, 1017-1032.

Fabiano M., P. Povero, G. Catalano and F. Benedetti (1991a) Hydrological data collected during the biological, chemical and geological sampling in Terra Nova Bay. In: National Scientific Commission for Antarctica, Oceanographic Campaign 1989-90. Data report I, pp. 35-71.

Fabiano M., P. Povero, R. Danovaro, D. Medica and R. Bruzzone (1991b) Particulate organic matter in Terra Nova Bay. In: National Scientific Commission for Antarctica, Oceanographic Campaign 1989-90. Data report I, pp. 73-112.

Fabiano M., P. Povero, R. Danovaro, D. Medica and R. Bruzzone (1991c) Distribution of particulate organic matter in Antarctic water (Ross Sea). In: National Scientific Commission for Antarctica, Oceanographic Campaign 1989-90. Data report I, pp. 113-137.

Fabiano M., P. Povero, R. Danovaro and R. Bruzzone (1992) Particulate organic carbon, nitrogen and nucleic acids (DNA, RNA) in Antarctic water (Ross Sea and Terra Nova Bay). In: National Scientific Commission for Antarctica, Oceanographic Campaign 1989-90. Data report II, pp. 153-178.

Fabiano M., Povero P. and Danovaro R. (1993) Distribution and composition of particulate organic matter in the Ross Sea (Antarctica). Polar Biology, 3, 525-533.

Hansen H. P. and K. Grasshoff (1983) Automated chemical analysis. In: Methods of seawater analysis, 2nd edition, K. Grasshoff, M. Ehrhardt and K. Kremling, editors, Verlag Chemie, Weinheim, pp. 347-379.

Hartree E. F. (1972) Determination of proteins: a modification of the Lowry method that gives a linear photometric response. Analytical Biochemistry, 48, 422-427.

Hecq J. H., P. Brasseur, A. Goffart, G. Lacroix and L. Guglielmo (1993) Modelling approach of the planktonic vertical structure in deep austral ocean. The example of Ross Sea ecosystem. Proceedings of the annual workshop on Belgian Oceanographic Research, Royal Academy of Belgium, pp. 235-250. 
Hedges J. I. and J. H. Stern (1984) Carbon and nitrogen determination of carbonate-containing solids. Limnology and Oceanography, 29, 657-663.

Holm-Hansen O., B. G. Mithell, C. D. Hewes and D. M. Karl (1989) Phytoplankton blooms in the vicinity of Palmer Station, Antarctica. Polar Biology, 10, 49-57.

Huntley M., D. M. Karl, P. Niiler and O. Holm-Hansen (1991) Research on Antarctic coastal ecosystem rates (RACER): an interdisciplinary field experiment. Deep-Sea Research, 38, 911-941.

Innamorati M., L. Lazzara, G. Mori, C. Nuccio and V. Saggiomo (1991) Phytoplankton ecology. In: National Scientific Commission for Antarctica, Oceanographic Campaign 1989-90. Data report I, pp. 141-252.

Jacques G. (1991) Is the concept of new production-regenerated production valid for the Southern Ocean? Marine Chemistry, 35, 273-286.

Jennings J. C., L. I. Gordon and D. M. Nelson (1984) Nutrient depletion indicates high primary productivity in the Weddell Sea. Nature, 309, 51-54.

Le Jehan S. and P. Treguer (1985) The distribution of inorganic nitrogen, phosphorus, silicon and dissolved organic matter in surface and deep water of the Southern Ocean. In: Antarctic nutrient cycles and food web, W. R. Siegfried, P. R. Condy and R. M. Laws, editors, Springer, Berlin, pp. 22-29.

Martin J. H. and S. Fitzwater (1988) Iron deficiency limits phytoplankton growth in the northeast Pacific subarctic. Nature, 331, 341-343.

Martin J. H., R. M. Gordon and S. Fitzwater (1990) Iron in Antarctic waters. Nature, 345, 156-158.

Mitchell B. G. and O. Holm-Hansen (1991) Observation and modelling of the Antarctic phytoplankton crop in relation to mixing depth. Deep-Sea Research, 38, 981-1007.

Moal J., V. Martin-Jezequel, R. Harris, J. F. Samain and S. A. Poulet (1987) Interspecific and intraspecific variability of the chemical composition of marine phytoplankton. Oceanologica Acta, 10, 339-346.

Nelson D. M. and W. O. Smith (1986) Phytoplankton bloom dynamics of the western Ross Sea ice edge-II. Mesoscale cycling of nitrogen and silicon. Deep-Sea Research, 33, 1389-1412.

Nelson D. M. and W. O. Smith (1991) Sverdrup revisited: critical depths, maximum chlorophyll levels and the control of Southern Ocean productivity by the irradiance-mixing regime. Limnology and Oceanography, 36, 1650-1661.

Nelson D. M, and P. Treguer (1992) On the role of silicon as a limiting nutricnt to Antarctic diatoms: evidence from kinetics studies in the Ross Sea ice-edge zone. Marine Ecology Progress Series, 80, 255-264.

Nelson D. M., W. O. Smith, L. I. Gordon and B. A. Huber (1987) Spring distribution of density, nutrients and phytoplankton biomass in the ice-edge zone of the Weddell-Scotia Sea. Journal of Geophysical Research, 92, 7181-7190.

Nelson D. M., W. O. Smith, R. D. Muench, L. I. Gordon, C. W. Sullivan and D. M. Husby (1989) Particulate matter and nutrient distributions in the ice-edge zone of the Weddell Sed: relationship to hydrography during late summer. Deep-Sea Research, 36, 191-209.

Niebauer H. J. and V. Alexander (1985) Oceanographic frontal structure and biological production at an iceedge. Continental Shelf Research, 4, 367-388.

Parsons T. R., M. Takahasky and B. Hargrave (1984) Biological oceanographic processes. Pergamon Press, New York, $332 \mathrm{pp}$.

Redfield A. C., B. H. Ketchum and F. A. Richards (1963) The influence of organisms on the composition of seawater. In: The sea, Vol. 2, M. N. Hill, editor, Interscience, New York, pp. 26-77.

Richards F. A. (1958) Dissolved silicate and related properties of some western North Atlantic and Caribbean waters. Journal of Marine Research, 17, 449-465.

Saggiomo V., L. Massi, M. Modigh and M. Innamorati (1992) Size-fractionated primary production in Terra Nova Bay (Ross Sea) during the austral summer (1989-90). In: Oceanografia in antartide, V. A. Gallardo, $O$. Ferretti and H. I. Moyano, editors, ENEA Progetto Antartide, Italia, pp. 289-294.

Sambrotto R. N., H. J. Niebauer, J. J. Goering and R. L. Iverson (1986) Relationship among vertical mixing, nitrate uptake and phytoplankton growth during the spring bloom in the southeast Bering Sea middle shelf. Continental Shelf Research, 5, 161-198.

Smetacek V. (1985) Role of sinking in diatom life-history cycles: ecological, evolutionary and geological significance. Marine Biology, 84, 239-251.

Smetacek V. and $\mathbf{P}$. Hendrikson (1979) Composition of particulate organic matter in Kiel Bight in relation to phytoplankton succession. Oceanologica Acta, 2, 287-298.

Smetacek V. and U. Passow (1990) Spring bloom initiation and Sverdrup's critical depth model. Limnology and Oceanography, 35, 228-233.

Smetacek V., R. Scharek, L. Gordon, H. Eicken, E. Fahrbach, G. Rohardt and S. Moore (1992) Early spring 
phytoplankton bloom in ice platelet layers from the southern Weddell Sea, Antarctica. Deep-Sea Research, 39, 153-168.

Smith W. O. and D. M. Nelson (1985) Phytoplankton bloom produced by a receding ice edge in the Ross Sea: spatial coherence with the density field. Science, 227, 163-166.

Steinhorn I. (1985) The disappearance of the long-term meromictic stratification of the Dead Sea. Limnology and Oceanography, 30, 451-472.

Tanoue E. (1985) Distribution and chemical composition of particulate organic matter in the Pacific sector of the Antarctic Ocean. Oceanographic Transactions-Tokyo University of Fisheries, 6, 43-57.

Treguer P. and G. Jacques (1992) Dynamics of nutrients and phytoplankton, and fluxes of carbon, nitrogen and silicon in the Antarctic Ocean. Polar Biology, 12, 149-162.

Treguer P., D. M. Nelson, S. Gueneley, C. Zeyons, J. Morvan and A. Buma (1990) The distribution of biogenic and lithogenic silica and the composition of particulate organic matter in the Scotia Sea and Drake Passage during autumn 1987. Deep-Sea Research, 35, 833-851.

UNESCO (1985) The international system of units (SI) in oceanography. Technical Papers in Marine Science, 45 , $1-95$.

Zentara S.-J. and D. Kamykowski (1981) Geographic variations in the relationship hetween silicic acid and nitrate in the south Pacific Ocean. Deep-Sea Research, 28, 455-465. 